\title{
The Nature, Philosophy, and Sustaining Factors of the Theology of Wealth in Africa: Theological Reflections
}

\author{
Daniel Dei, Robert Osei-Bonsu \\ Valley View University
}

\begin{abstract}
This paper is a theological reflection on the theology of wealth in Africa-its nature, philosophy, and sustaining factors. Through the methodology of theological reflections, the paper finds out that the theology of wealth, though difficult to describe, is sustained on the African continent by economic hardship, the influence of some preachers of the theology of wealth, and the availability of improved facilities for disseminating the content of the theology of wealth. It also finds out that the entire philosophy of the theology of wealth is biblically, theologically, and ethically deficient. Biblically, it adapts parts of scripture to suit its teachings. Theologically, it puts forth viewpoints that are foreign to theological thought. Ethically, it is a means of exploiting congregants. The paper concludes with a recommendation that the content and nature of the theology of wealth must be highlighted and thoroughly explained to both clergy and membership of different denominations so that all will be safeguarded against the impact of this false gospel on their lives.
\end{abstract}

Keywords: Africa, Christianity, wealth, flamboyance, theology, economic success, materialism, penteco-charismatic

\section{Introduction}

Wealth has been defined as the "abundance of money and valuable material possessions" or "the state of being rich” (Allen 2003, 1119). In Africa, it appears that the popular definition of wealth emphasizes the abundance of valuable goods, fertility, good health, good marriages, good job, etc.. Such focus is termed materialism—an unhealthy obsession for physical gains (Ndyabahika 2007, 79). In the theological enterprise, the theology of wealth or the prosperity theology, or materialism, is generally understood to mean a body of Christian religious belief and practice stressing that the abundance of valuable goods: money, fertility, good health, good and satisfying marriage, lucrative jobs, etc., is the ultimate end that God has appointed for every Christian "and that donations to Christian ministries will always increase the Christians (Umoh 2013, 657)" accumulation of these valuables. However, the authors believe that a biblical view of wealth, while including such valuable goods such as money, fertility, good health, good and satisfying marriage, lucrative jobs, etc., ultimately aims at eternal life found or realized only in relationship with Jesus Christ.

Yet it seems that wherever the popular notion of wealth or materialism tends to be the focus of a religious faith, attention shifts from modesty to the acquisition of wealth whether through fair or foul means. In such communities, money, fame, and flamboyant lifestyles are extolled to the neglect of cherished virtues such as the

Daniel Dei, lecturer, School of Theology and Missions, Valley View University, Ghana; main research fields: Ethics and Society. Email: deidaniel@yahoo.com.

Robert Osei-Bonsu, senior lecturer, rector, Valley View University (Techiman Campus), Ghana; main research fields: Historical-Theological Studies, Ethics, and Philosophy. Email: pastorbonsu@hotmail.com. 
sanctity of human life and the undying pursuit for the general good of all. The attitude of acquiring wealth, with its harmful effects, has become deep seated that nearly all areas of life in Africa have been affected.

Christianity has equally not been left out. Popularly known as prosperity theology, the theology of wealth seems to have gradually become almost an established doctrine of the Christian faith. At its core is the notion that "financial blessing is the will of God for Christians, and that faith, positive speech, and donations to Christian ministries will always increase one's material wealth” (Asamoah 2013, 198). Thus, the ultimate goal of the theology of wealth is material success represented by the overt emphasis on money, healing, fame, good marriages, good jobs, visas to desired places abroad, and pregnancies. The quest for wealth at all cost runs contrary to the moderate usage of wealth long advocated by the Christian faith. Thus, Umoh $(2013,657)$ rightly observes that the "prosperity Gospel is an aberrant theology, based on a non-traditional interpretation of the Bible and the teaching that God rewards faith and tithing with material well-being.” The emphasis on wealth and healing among some African Christians is so acute that other values such as love, mercy, devotion to God, and faithfulness to one's God-given duty in life are neglected. Obiora's (Umoh 2013, 658) comments ring a bell here. He indicates that: In recent times... A new wave of Christian message is convulsively sweeping through the world like harmattan bush fire. It reads: Wealth not poverty; treasure not good deeds; flamboyance not the humble cassock; prosperity and earthly comfort not patience in tribulations.

True to Obiora's comments, the theology of wealth continues to impact Christianity in Africa today. It seems to rewrite the principles of Christianity stressing wealth, healing, fame, and flamboyance in place of the long-cherished virtues of the Christian faith love, hope, steadfastness, self-control, reticence, contentment, and simplicity. If the impact of the theology of wealth on Christianity in Africa continues unabated, there will be a genuine fear that the center of Christianity in Africa will completely move from God to miraculous break-through geared toward materialism in all of its facets. Briefly, it could be asked: What future does the theology of wealth have for the evangelization and disciple of prospective Christians on the African continent?

It is against this backdrop that this paper has been composed. Theologically, the paper reflects on the nature, philosophy, and sustaining factors of the theology of wealth in Africa. Also, it examines the whole phenomenon of prosperity theology on the basis of relevant biblical passages. Structurally, the paper is sub-divided as follows: the nature of the theology of wealth; the philosophy of the theology of wealth; the sustaining factors of the theology of wealth; reflections; conclusion; and recommendations.

\section{Nature of the Theology of Wealth}

The theology of wealth emerged from the faith movements in America in the early 20th century (Mombi 2009; Akoko 2007). From America, it has spread to other parts of the world including Africa through the Charismatic movement. Akoko $(2007,60)$ states that the genesis of the prosperity gospel's "historical development is traceable through well-known evangelists like E. W. Kenyon, A. A. Allen, Oral Roberts, T. L. Osborn, Kenneth Hagin, Kenneth Copeland, etc..” On the African continent, it has been variously manifested in the worship styles of different congregations to the extent that an exact description of its nature appears difficult. However, the authors have attempted a description of its nature based on observable features.

First, the theology of wealth, as practiced in Africa, shares common characteristics with the traditional Charismatic movement. This is especially true with regards to the dominant idea that Christian salvation implies living a "well-fulfilled Christian life," making the essence of salvation "this-worldly" (Umoh 2013, 657). Similar to the practice of the theology of wealth in Africa, Asamoah $(2013,199)$ observes that the 
"Penteco-charismatic churches believe that healing, liberty, freedom, happiness, peace, and long life are components of salvation. So as soon as one receives salvation in Christ, one is privileged to have these blessing if other principles are followed.”

By this observation, it can be seen clearly, then, that the tradition of the penteco-charismatic movement creates the environment for the dissemination of the theology of wealth. Thus, it comes as no surprise when Umoh $(2013,659)$ notes that "the majority of today's advocates of the gospel (of wealth) are mostly Pentecostals.”

Second, the practice of the theology of wealth is marked by enormous "worship arena," "large crowds," and the "exemplary opulence of advocate pastors" (Umoh 2013, 658). These worship arenas, otherwise known as worship centers with a biblical word or phrase as code name, are so magnificent that they attract lovers of the flamboyant type of life into their fold. One other way of generating a large following is the practice of holding frequent or occasional worship services or healing miraculous crusades in nationally noted edifices such as stadiums, independence parks, conference centers, or hotels. Such gatherings are advertised on huge billboards, "aired live on televisions" (Umoh 2013, 658), and radios. The purpose of this is two-fold. One is to display the popularity of advocate-pastors and denominations, and two is to pull crowds to their gatherings.

Third, advocate-pastors live in flamboyance. Their showiness is expressed in their dressing, the nature of their homes (buildings), always seen in the company of guards (even in the worship setting), and the vehicles they use. Some have gone to the extent of owning fleets of private jets. As Umoh $(2013,665)$ indicates, "most of these pastors have more than one expensive private aircraft." Though such a practice presents a paradox to the critically minded Christian, this exemplary display of material success is taken as proof of their divine mandate and a seal of divine authentication (Umoh 2013, 658). In most cases, it seems as if adherent-pastors appeal to people by calling attention to their ostentatious display and setting it as the epitome of the blessed life in Christ.

Fourth, nearly all Christian denominations or ministries employing the theology of wealth insert the word "international" in their name. In most African countries, it is not uncommon to find a congregation of about 20 persons with the word "international" being part of their name. In truth, the denomination (ministry) may not have any branch abroad, yet they add the word "international" to their name. In some cases, the adherent-pastor styles himself/herself as an international preacher, evangelist, bishop, or reverend. In obscure, yet real cases, adherent-pastors in Africa invite their white friends without any clerical responsibilities whatsoever, to come and "pose as international representatives of their ministries" (Umoh 2013, 659).

Lastly, practicing the theology of wealth is frequented by the "breakthroughs" in the worship services. Nearly all their worships end with deliverance services from either physical maladies or poverty. Usually, the former occupies the center stage. The notion underlining such practice is that the blessings from God exclude discomforts in life. Foster correctly captures this point indicating that:

Money is a sign of God's blessing, and hence poverty is a sign of God's displeasure. This has been turned into a religion of personal peace and prosperity: crudely stated, "Love Jesus and get rich". Many churches are saturated with readily available gimmicks for blessedness, all the way from exact mathematical formulas (God will bless you sevenfold) to much more subtle but equally destructive forms. (Umoh 2013, 659)

By considering the nature of the theology of wealth as it is practiced in Africa, it should be noted that any of the above descriptions could fit other Christian denominations which may not employ the theology of wealth. 
The difference is that Christian denominations and ministries practicing the theology of wealth measure God's blessings in material terms only, whereas other Christian denominations and ministries, opposed to the theology of wealth, strongly emphasize the immaterial conception of God's blessings. To the former, salvation in Christianity is "purely carnal and materialistic" (Umoh 2013, 658) which involves "liberation from poverty, earthly miseries, sicknesses, bad business, and unsuccessful marriages” (Umoh 2013, 658). But to the latter, salvation involves admittance into the New Jerusalem to live in the presence of the Lord. Thus, it stresses the moderate usage of wealth. Consequently, it could be seen that while the theology of wealth emphasizes that wealth or prosperity is an end in itself, orthodoxy, on the other hand emphasizes that wealth or prosperity is only a means to an end.

\section{Philosophy of the Theology of Wealth}

The practice of the theology of wealth is based on some principles understood by adherents as divine principles of faith. These principles underline the core teachings of the practice in Africa. Fundamentally, there are five of these principles that invariably operate in the spiritual realm to ensure that adherents will materially benefit from the practice. These principles are: the law of God's blessings, the law of divine reciprocity, the law of faith, the law of positive confessions, and the expiatory work of Christ.

\subsection{The Law of God's Blessing}

This law is based on the divine blessings of the Abrahamic covenant (Gen 12: 1-3). According to proponents of the theology of wealth, the promised blessing is a material one. Gifford suggests that:

The essential point of prosperity is that prosperity of all kinds is the right of every Christian. God wants a Christian to be wealthy. True Christianity necessarily means wealth, and it inevitably brings wealth... abundant life gospel which includes financial blessing, fertility, health, protection, good wife, children, and long life. (Asamoah 2013, 205)

Since Christians, by virtue of faith, are descendants of Abraham (the father of faith) and heirs of this covenant, this material blessing includes them, too. Therefore, financial blessing "belongs to us here and now, and we must 'prosper in all areas of life'” (Mombi 2009, 42). Larbi argues that:

The blessing of God came upon Abraham and made him rich! The Bible did not say Abraham became rich spiritually; you see, when God blesses you, that blessing will show in every aspect of your life, even as far as material possessions are concerned. Listen! The times are changing! The time when believers were looked down upon, considered as downtrodden and nobodies in society are past and gone! The time has come for people to look at believers and look at them twice! God is blessing his people, and that blessing is causing them to prosper. Prosperity has powerful effect of transforming an individual who is poor to become rich (Prov. 10: 32). God wants above all things to prosper us and be in good health even as our souls prosper 3 John 2 [sic]. If God did not want us to prosper, why should he teach us how to prosper? God want [sic] us to prosper in our marital life, child upbringing, profession, business, and any other part of our lives. (Asamoah 2013, 206)

Based on this principle, proponents of the theology of wealth teach that poverty, sicknesses, bad marriages, frustrations, disappointments, unemployment, or bad jobs are curses and so they should never be the portion of the true Christian who is a spiritual heir of the covenant blessings.

\subsection{The Law of Divine Reciprocity}

Otherwise, known as the "law of sowing and reaping" (Mombi 2009, 42), this principle states that "give and it will be given back unto you" (Asamoah 2013, 198). Based on Mark 10: 29-30, proponents of the 
theology of wealth suggest that the act of giving is like engaging God in a giving competition. Since nobody can out-give God, such a Christian will have endless blessings of prosperity and healing. The encouragement to continually give is well expressed by Saracco (Mombi 2009, 42). He writes "whoever puts into practice, this law would practically enter into a cycle of endless wealth.” For this reason, members are almost always counseled to sow seeds in the form of money. Klassen (Asamoah 2013, 199) is right in his observation that such congregations place "strong emphasis on the importance of giving and leaders often bestow a specific blessing on the money being donated, and some have even been reported to instruct worshipers to hold their donations above their heads during the prayer."

Though such a practice, as observed by Klassen, is common among adherent congregations, Akoko indicates that when an adherent church is involved in a project, which calls for "much money to accomplish, the theme of most of the sermons during the period would dwell on the gospel of prosperity and also when an announcement concerning the project is being made, members are often reminded of the gospel in a bid to persuade them to raise money relentlessly for the project” $(2007,80)$. Obviously, this attitude of constant giving by members of adherent congregations supports the huge budgets of the pastors and ministries of congregations in favor of the theology of wealth.

\subsection{The Law of Faith}

Just as natural laws operate in the physical realm, faith functions in the spiritual realm. Proponents of the theology of wealth posit that with the right kind of faith in God, human beings could cause God to deliver his promises of "security and prosperity" (Asamoah 2013, 198) as well as healing, good businesses, marital happiness, responsible children, and peace to them. Briefly, this principle states that "act with faith, name what you want with certainty, and it becomes reality" (Mombi 2009, 43). This principle is based on the manner in which proponents understand scriptural passages such as Mark 11: 22-23 and Matt 7: 7. With reference to the former passage, Mombi $(2009,43)$ is of the view that the clause "have faith in God" refers to "the faith of God" that is functional at creation. With such a faith, then, nothing should be hard or difficult for the true Christian. Material prosperity is his or hers for the asking.

\subsection{The Law of Positive Confessions}

In the thought of proponents of the theology of wealth, it is not enough to have faith. Rather faith must be expressed in the form of positive statements. This principle states that if you "confess what you believe," it will “materialize” (Mombi 2009, 43). The underlining notion is that "Christians have been given power over creation because they are made in the image of God and teach that positive confession allows Christians to exercise dominion over their souls and material objects around them" (Asamoah 2013, 199). Based on Mark 11: 23-24, proponents teach that you possess when you confess and you acquire it when you name it. Consequently, adherent congregants "are encouraged to speak positive statements about aspects of their lives that they wish to see improved" (Asamoah 2013, 198). This explains why there are frequent shouts of the statement "I claim..." during worship services of adherent congregations. Usually, the "I claim" statement is said in response to positive statements which preachers make in the course of sermonizing.

\subsection{The Expiatory Work of Christ}

Since poverty, sicknesses, frustrations, bad marriages, childlessness, unemployment, and bad jobs are all curses, the sacrifice of Jesus Christ has done away with all of them. Hence, the true Christian should not 
encounter any of such curses in his or her life. In the context of the theology of wealth, therefore, the efficacy of the death of Christ is seen in only material or economic terms-suffering in whatever form is inconsistent with genuine Christianity. Based on Isa 53: 3-4, proponents indicate that "divine healing" and "material prosperity” are the main results of Christ’s death (Mombi 2009, 43). Gifford adds that:

According to the gospel, God has met all the needs of human beings in the suffering and death of Christ, and every Christian should now share the victory of Christ over sin, sickness, and poverty. A believer has a right to the blessings of health and wealth won by Christ, and he or she can obtain these blessings merely by a positive confession of faith. (Akoko, 67)

From the highlight of the philosophy undergirding the theology of wealth, it appears as no surprise that this movement has many followers. Without a careful analysis of the biblical references serving as base for the theology of wealth, one is likely to be misled into believing that God's intention for Christians is material success at the expense of spiritual blessings. In spite of its biblical defects, the theology of wealth continues to spread across the continent of Africa. What could be the factors?

\section{Sustaining Factors of the Theology of Wealth in Africa}

The spread of the theology of wealth in Africa has been the results of many factors. These factors could be classified into three. These are the economic factor, influence of some preachers of the theology of wealth, and the availability of improved facilities for disseminating the content of the theology of wealth.

\subsection{The Economic Factor}

Fundamentally, many countries in Africa are economically challenged. With this economic crisis comes financial difficulties leading to a fall in the general standard of living of individuals. Consequently, the "high rate of unemployment, inflation, and poor living conditions” (Umoh 2013, 660) that have ensued in these countries cannot be overstated. Generally, there is economic hardship on the continent. This hardship has eaten deeper into the fabric of society to the extent that nearly all dimensions of life in Africa are affected—bad jobs, broken homes, unemployment, and inability to pursue educational goals.

This dire condition prevalent on the continent of Africa has been well described by Nwankwo and Ibegbunam (Umoh 2013, 660). According to them, "hunger, disappointments, anxieties, and hopelessness have been the lot of a great many." Coupled with this economic difficulty, is the general unprecedented rate of crimes on the continent. Umoh $(2013,661)$ could not be more correct in his observation that "criminality such as armed robbery, kidnapping, and terrorism are on the increase. There is a lot of insecurity and many people have been stretched beyond the limits of their endurance. And only naturally, the result is a little of broken persons and broken homes: all in need of restoration.”

Against the back drop of this economic hardship, it is not surprising when many Africans look to religion as a means of escape. Both pastors and members of their congregations appeal to religion for "breakthroughs" and release from the restraints of lack. Mombi is of the view that:

With the given economic situation and churches struggling financially, what a relief to know the secrets of prosperity. Give to God, and God will give you 100 times more, and your barns will overflow, because you are entering into "God's cycle of endless wealth”. You hold the key to your prosperity. All you need to do is to have faith, think positively, confess what you need/want, and receive it. $(2009,43)$

Hence, the theology of wealth has and continues to spread on the continent of Africa. 


\subsection{The Influence of Some Preachers of the Theology of Wealth}

The fame of some proponent preachers of the theology of wealth has contributed to the rapid embrace of this theology in Africa. Both western preachers and their local counterparts could be cited as evidence of this notion. In the international front, Reinhardt Bonnke, a German-born "best-known Western crusader" (Akoko 2007, 73) has impacted the spread of the theology of wealth in no small measure. The teachings and sermonizing of other Africans such as Arch-Bishop Benson Idahosa of blessed memory, Matthew Ashimolow, and Chris Oyakhilome (all of Nigeria), Handel Leslie of Uganda, Arch-Bishop Duncan Williams, Dr. Mensa Otabil, and Arch-Bishop Charles Agyin-Asare (all of Ghana), Reverend Dr. Billy Lubunsa and Zacharias Fomum (all of Cameroun) have also contributed immensely to the spread of the theology of wealth in Africa (Akoko 2007, 33, 60). These men of God are very influential in their countries and are regarded as opinion leaders. The influence of some of these preachers is not only limited to their congregants but is felt economically, sociologically, and politically in their countries and sometimes even beyond.

\subsection{The Availability of Improved Facilities for Disseminating the Content of the Theology of Wealth}

Due to the advancement in the information technology industry, many modes of spreading the message of the theology of wealth are now available. One traditional mode of communication is through "sermons during regular Sunday worships, rallies, media, material objects, and the lifestyle of the leaders” (Akoko 2007, 80). Other methods include the use of radio, television, and other social media platforms, namely, Facebook, WhatsAPP, Twitter, and text messages sent upon request on cell-phones. Most proponents of the theology of wealth utilize one or more media for communication.

\section{Reflections}

Given the general unprecedented frustrations and hardship on the African continent, the theology of wealth has succeeded in inducing Africans to focus upon God. According to Umoh (2013, 661, word in bracket supplied), the "prosperity Gospel has put God back at the center of human experience by positing God as more than capable of meeting all the needs of desperate [Africans]." Yet the theology of wealth has many defects when examined against the background of the Bible, theology, and ethics.

Biblically, the philosophy of the theology of wealth has been criticized as propagating false teachings which gravely distort the Bible (Asamoah 2013, 206). Evidently, some of the scriptural passages used as bases for explaining the tenets of this gospel, are often quoted and applied out of context. For instance, Gen 12: 1-3 is used by proponents to teach that God's promise in the Abrahamic covenant, which is materialistic, applies to all true Christians. Hence, all true Christians are expected to be materially rich because Abraham is materially blessed and prosperous. 3 John 1: 2 is used in this vain to lend credence to the notion that the divine plan for all true believers is that they become rich materially and in health. However, a critical study of Gen 12: 1-3 suggests that the covenant blessings mean much more than material success. Sharing this view, Nichol explains that:

The blessing vouchsafed to him (Abram) would finally unite divided families on earth, and change the dread curse pronounced upon the ground because of sin into a blessing for all men. All further promises to the patriarchs and Israel either clarified or amplified the promise of salvation offered the entire human race in the first promise made to Abram. (1956, 294, word in bracket supplied) 
Indeed, it is only a spiritual blessing that could cure the curse wrought by sin upon the entire humanity. Similarly, 3 John 2 illustrates that wholesome state of wealth or prosperity involves both material (physical) and spiritual well-being (Gaebelin 1984, 371). Nichol $(1956,695)$ indicates further "here the reference appears to be to Gaius' spiritual life, which was strong. It was possible that his physical condition was not so good. He may have neglected the physical concerns of life for the religious. Such neglect is harmful; balance is essential to successful living.” Thus, both passages have different focus than that being imposed on them by adherents of the theology of wealth. While the blessings of God including material success extend beyond it, it concerns itself with the ultimate- the restoration of the relationship between humanity and God (salvation). God's purpose for everyone is that all should be saved (Jn 3: 16).

Another biblical text used as basis for the prosperity gospel is Mark 10: 29-30. Based on this passage, proponents aver that God continuously showers his abundant gifts of material success on the true believer who gives to the church ministries and the pastors adhering to the theology of wealth, but was the focus of Jesus' promise limited to this life alone. Certainly not, Gaebelein $(1984,717)$ has suggested that "the hundredfold return in this life (VS. 30) is to be understood in the context of the new community into which the believer in Jesus comes. There he finds a multiplication of relationships, often closer and more spiritually meaningful than blood ties." Here again, wealth is seen as including material and spiritual components, yet the latter is far more important than the former.

Also, Mark 11: 22-24 and Matt 7: 7 have been used as bases for spreading the message of the theology of wealth. Proponents suggest that "faith" in these passages means the "faith of God." According to them, God uses this faith in creation. Hence, with such faith in possession, the true Christian may acquire whatever he or she desires and it shall be realized materially. This is a clear case of forced interpretation on the passage. In the first place, God does not need to have faith. Hence, taking "faith" to mean the "faith of God" is out of context (Mombi 2009). Whereas the passage offers lessons on prayer and faith, it does not warrant the use of faith for mundane activities. Rather, it teaches that God must be the object of our faith. Stressing on this point, Stauffer states:

What is it that distinguishes this faith from the self-intoxication that... is beyond one's powers and makes a man and his work end up in a fiasco? The "faith" of Mark 11: $23 \mathrm{f}$ is a faith that prays... prayer is the source of power and the means of its strength—God's omnipotence is its sole assurance, and God's sovereignty is its only restriction. (Gaebelein 1984, 729)

In the same way, the passage in Matt 7: 7 has been adapted to read as proponents of the theology of wealth want it to mean. In its right context, Jesus' main concern is a disclosure of "the means by which citizens of his kingdom can make these noble graces [the eight main virtues listed in the Sermon on the Mount (Matthew 5 and 6)] part of their lives... All that citizens of the kingdom need is theirs for the asking" (Nichol 1956, 356, words in bracket supplied). Gaebelein $(1984,186)$ adds that "such praying is not for selfish ends but always for the glory of God according to kingdom concerns. So here: the Sermon on the Mount lays down the righteousness, sincerity, humility, purity, and love expected of Jesus' followers; and now it assures them such gifts are theirs if sought through prayer.” On this framework, Broadus (Gaebelein 1984, 186) has observed that "one may be a truly industrious man, and yet poor in temporal things; but one cannot be a truly praying man, and yet poor in spiritual things.” Properly understood, therefore, these texts appear to focus on faith in God's will and God's sovereignty.

Furthermore, proponents of the theology of wealth strongly hold that the sacrifice of Christ on behalf of humanity is for the total release of humans from the bondage and curse of sin. They explain that such curse or 
bondage includes poverty, sicknesses, frustrations, misfortunes, unemployment and bad jobs, bad marriages, childlessness, unprogressive lifestyles, as well as anything that causes sorrow or grief. Since this curse has been removed, the goal of true Christianity (material wealth or economic success) can be realized by all Christians. Proponents claim that Isa 53: 4-5 supports such a viewpoint.

Additionally, the phrase "abundant life" in the scriptural passage in John 10: 10 is taken to mean a life of material and economic success free from the discomforts of life whatever they may be. But the sacrifice of Christ is basically expiatory and propitiatory-it saves humanity from sin and its guilt, not salvation from material poverty. Here an insight into the meaning of the Greek zoe may be helpful. "In its theological sense, zoe is equivalent to eternal life." Since the sin of Adam and Eve causes them to lose this life, Jesus comes to restore this zoe in humanity.

Life includes the physical, intellectual, and spiritual. Physical life is regarded as abundant in a body that is full of vigor and in perfect health. Jesus' miracles of physical healing gave an abundant physical life to those whose life forces were ebbing. But physical restoration was by no means the complete fulfillment of Jesus' mission. Man also has intellectual and spiritual life, which must also be made alive and abundant, for "man doth not live by bread only, but by every word that proceeds out of the mouth of the Lord” (Deut, 8: 3). Important as the physical and the intellectual aspects of a well-rounded life are, no life is fully complete unless the spiritual nature is nurtured. (Nichol 1956, 1005)

Here again, the point has been made that biblical prosperity involves something more than material success. Ultimately, it aims at eternal life found only in Jesus Christ. In Christ, our faith is to be directed.

From the foregoing, it could be inferred that the biblical basis for the theology of wealth is rickety. At best, scriptural passages are adapted to suit the pursuit of endless desire for material and economic success. Thus, the philosophy of the theology of wealth has an inherent hermeneutical defect that needs urgent correction.

Theologically, two questions seem inadequately answered by the philosophy of the theology of wealth. First, what is the ultimate goal of the Christian life? In the thought of proponents of the theology of wealth, the goal of Christianity is material wealth and economic prosperity. Expressed by Larbi, "true Christianity necessarily means wealth, it inevitably brings wealth. Conversely, poverty indicates personal sin, or at least a deficient faith or inadequate understanding" (Asamoah 2013, 205). In other words, the ultimate goal of true Christianity is a life of flamboyance, comfort, and ease. What this means is that any Christian who is either suffering under one malady or the other, or wallowing in abject poverty, is not genuine. In light of this, how do we explain the suffering of job, the life of the earthly parents of Jesus, or even some of the apostles, including Paul? Over and over again, the Bible impliedly underscores the fact that material wealth or economic success is never the basis for assessing the spiritual status of Christians (Matt 26: 11; Deut 15: 11, Psa 22: 26; 34: 6; 40: 17; Prov. 22: 2, 22-23; 23: 4-5). Asamoah expounds this point in details. He writes:

This means: If a Christian is not rich or wealthy in material sense, it does not mean he/she has a sin problem or lacks faith or lacks understanding of the Scriptures per se. We have genuinely good Christians-living in holiness, who pay their tithes, have faith in God, and are not prosperous at the moment. God does not also necessarily make one rich just because he/she pays tithes correctly. Besides, becoming a Christian does not automatically usher one into material blessing. Material blessings are not the goal of Christianity. There is also a dimension of blessings that is spiritual, not tangible that the Christian must pursue. $(2013,205)$

Jesus, in counsel to the rich young ruler who inquires from him the prerequisite for eternal life, seems to have raised the ultimate goal of the Christian life beyond materialism (Mark 10:17-22). In the said encounter, Mark writes “... one thing you lack: Go your way, sell whatever you have and give to the poor, and you will 
have treasure in heaven; and come, take up the cross, and follow me (10: 21)." For this ruler with great possessions or material things (VS. 22), what could be told to do such is an indication that the goal of Christianity extends beyond materialism. In this context, the ultimate goal of Christianity is revealed as "eternal life.” This is only attainable as one follows Jesus Christ—a fact that eluded the young rich ruler. Therefore, Christian prosperity could be described as a state of perfect communion with Jesus Christ (Matt 6: 33).

Another theological question that should be addressed by proponents of the theology of wealth is the function of faith and God's will. In this vain, it could be asked: Do individuals get material wealth or economic success because they claim or confess in faith those wealth or success; or do individuals acquire material wealth or economic success because such wealth is determined by God for them? For proponents of the theology of wealth, all that one needs to get rich is to identify your needs, have faith in God that whatever you ask him shall be granted, express aloud this need, and see your need realized. However, this is highly inconsistent with the Bible. Throughout its pages, one can find ample evidence indicating that wealth or riches are the results of God's blessings, ensuing from his will (Josh 1: 8; Deut 8: 17-18; Psa 145: 15-16; Prov. 10: 22, Jas 1: 17). Asamoah $(2013,205)$ shares the same view: "in actual fact, God desires and plans for the prosperity of his children, but the realization of this although, man (humanity) plays a good role, is actually God's will for man (humanity) that prevails.” Indeed, one thinks of the grace of God that enables one to acquire material wealth or economic success, then, it follows that all wealth, whether material or spiritual emanates from God. Thus, the view that we possess what we confess is at variance with scripture.

Clearly, it could be seen, then, that the teaching of positive confessions in the theology of wealth is foreign to the Bible. Rather, it finds its basis in the pagan law of attraction. According to this law, individuals are responsible for the things that happen to them as well as the situations they find themselves in at any time (Scott 2009). By thinking of good things, the law says, good things will actually come the way of the individual. Introduced into Christianity, the law of attraction has been imposed on the scriptural passage such as Prov. 23: 7. However, resort to the immediate context of the passage indicates a counsel on one's relationship with a miser. In this regard, some teachings of the theology of wealth could be seen as coming from purely unchristian background and syncretic for that matter.

Ethically, the theology of wealth is seen as a way of commercializing the Gospel of Jesus Christ. In this commercial enterprise, the true Gospel is replaced by "love for, reverence for, and adoration of the world and its mammon appears to be given justification as blessing from salvation” (Asamoah 2013, 206). In this regard, the theology of wealth has been described as a "false gospel" (Asamoah 2013, 206). This is mainly because it posits an acute yearning for self-centered materialism instead of focusing on the life, teaching, and personal characteristics of the Son of God, whom to know is life eternal (Jn 17: 3). It appears as though the only beneficiaries of the theology of wealth are the pastors who advocate it. While they live in extreme splendor, their congregants live in abject poverty (Asamoah 2013; Umoh 2013). For this reason, Asamoah (2013, 207) remarks that "Christians today must be cautioned consistently not to pursue after material wealth; rather they must be motivated to pursue righteousness, godliness, faith, love, endurance, and gentleness.” In light of this, the practice of the theology of wealth is only an exploitative means whereby its advocates, especially pastors, acquiring unfair wealth at the expense of their ignorant congregants.

\section{Conclusion}

In this study, the authors have attempted a theological reflection on the theology of wealth in Africa with 
regards to its nature, philosophy, and sustaining factors. A careful study of the philosophy of the theology of wealth has revealed that it is biblically, theologically, and ethically unbalanced. Biblically, it comes out that some scriptural passages have been adapted to suit its teachings. Theologically, it is observed that the role of faith as well as the definition of wealth or the prosperity propagated by the theology of wealth is at variance with genuine theological thought. In true Christian thought, wealth or prosperity means much more than mere material wealth or economic success. While including material wealth or economic success, real prosperity is ultimately perceived as eternal life realized only in Jesus Christ. Also, God's sovereign will determine everything that comes to humanity in the form of wealth—whether it is physical or spiritual. Ethically, the paper finds out that the emphasis on material wealth or economic success at the core of the theology of wealth at the expense of devotion to God, love, godliness, contentment, long-suffering, etc., is licentious. From this context, the authors strongly suggest that the theology of wealth is a false gospel and ought to be rejected by all genuine Christian denominations and persons.

\section{Recommendations}

Based on the outcome of the theological reflection on the nature, philosophy and sustaining factors of the theology of wealth in Africa, the authors generally recommend that necessary measures should be employed to safeguard true Christianity from being distorted by the practice of the theology of wealth. In light of this, the following suggestions have been put forth:

Christian denominations and clergy must develop a genuine theology of suffering. Such a move will address the inadequate understanding that most Christians in Africa have concerned the high spurt of poverty on the continent.

Christian denominations must clearly define real biblical wealth or prosperity. This definition will go a long way to dispel the erroneous view given to wealth or prosperity by the false teachings of the theology of wealth.

Christian denominations must establish measures that maintain standards of modesty in ministerial leaders. Such move will curb the flamboyance that attracts other individuals to look on the Gospel Ministry as an economic or financial venture.

Christian denominations, clergy, and Bible workers in Africa must relate the Gospel to real issues of concern to Africans. As members are prepared for eternal life and the hereafter, they must also be prepared to live this life, the here-and-now, as they await the ultimate. Establishing schools, hospitals, scholarship schemes, and guidance on life choices, intensifying pastoral care, and organizing conferences, seminars, and workshops on spiritual and economic management will yield so much in this direction. Additionally, such activities will make the Gospel relevant to the present-day African.

\section{Works Cited}

Akoko, Robert Mbe. “Ask and You Shall Be Given:” Pentecostalism and the Economic Crisis in Cameroon. Leiden, Netherlands: African Studies Center, 2007.

Allen, Robert. The Penguin English Dictionary. London: Penguin Books, revised edition, 2003.

Asamoah, Moses Kumi. "Penteco-Charismatic Worldview of Prosperity Theology.” African Educational Research Journal 1.3 (2013): 198-208.

Bediako, Kwame. Jesus and the Gospel in Africa. Maryknoll: Orbis Books, 2004. 
Cotterell, Peter. Prosperity Theology. Leicester: Religious and Theological Studies Fellowship, 1993.

Dowden, Richard. “In Africa, Does Prosperity Bring Peace? Lessons from Somalia to Mozambique.” African Arguments:

< http://africanarguments.org/2013/10/28/in-africa-does-prosperity-bring-peace-by-richard-dowden/> . March 14, 2014.

Gaebelein, Frank E.. The Expositor's Bible Commentary, Vol. 6, 8, \& 12. Grand Rapids: Zondervan, 1984.

Hunt, Stephen. “'Winning Ways:' Globalization and the Impact of the Wealth and Health Gospel.” Journal of Contemporary

Religion 15.3 (2000): 332.

Jones, David W.. “Errors of the Prosperity Gospel.” <http://www.9marks.org/blog/errors-properity-gospel>. March 21, 2014.

Jeremiah, David. "Prosperity Theology. Christianity Today." <http://www.christianitytoday.com/biblestudies/articles/theology/ prosperity>. March 19, 2014.

Kasera, Basilius M.. “The Biblical and Theological Examination of Prosperity Theology and Its Impact Among the Poor in Namibia.” A Master’s Thesis: South African Theological Seminary, unpublished, 2012.

Klassen, Michael J.. Strange Fire, Holy Fire: Exploring the High and Lows of Your Charismatic Experience. Grand Rapids: Baker Publishing Group, 2009.

Koch, Bradley A.. “The Prosperity Gospel and Economic Prosperity.” Doctoral thesis: Indian University, unpublished, 2009.

Mombi, George. "Impact of the Prosperity Gospel in the Assemblies of God Churches of Papua New Guinea." Melanesian Journal of Theology 25.1 (2009): 32-58.

Morris, Russell A. \& Lioy, Daniel T.. Conspectus: The Journal of the South African Theological Seminary 12 (2012): 73-115.

Ndyabahika, James. "Biblical Economy, Weath, and Poverty: A Challenge to the Great Lakes Region of East Africa.” McMaster Journal of Theology and Ministry 8 (2007): 64-81.

Nichol, Francis D.. The Seventh Day Adventist Bible Commentary, Vol. 1, 4, 5, \& 7. Washington: Review and Herald Publishing Association, 1956.

Scott, Page E.. "Understanding and Using the Law of Attraction in Your Life.” <URL:http://stress.about.com/od/ optimismspirituality/a/attraction21807.htm>. March 11, 2014.

Stephenie, Mitchem Y.. Name it and claim it: Prosperity Preaching in the Black Church. Ohio: The Pilgrim Press, 2007.

Umoh, Dominic. "Prosperity Gospel and the Spirit of Capitalism: The Nigerian Story." African Journal of Scientific Research 12.1 (2013): 653-68. 